\title{
Energy requirements for a dense population of rock lobsters Jasus lalandii: novel importance of unorthodox food sources
}

\author{
Amos Barkai, George M. Branch \\ Zoology Department and Marine Biology Research Institute, University of Cape Town, Rondebosch 7700, South Africa
}

\begin{abstract}
Standing stocks of South African rock lobster Jasus lalandii vary considerably from site to site. In this paper 2 adjacent island sites are compared. One supports an extremely dense population of rock lobsters with an estimated biomass of some $3.9 \mathrm{~kg}$ wet weight $\mathrm{m}^{-2}$ and a calculated energetic requirement of $36 \times 10^{3} \mathrm{~kJ} \mathrm{~m}^{-2} \mathrm{yr}^{-1}$, while the other has almost no rock lobsters. A key question is how the dense population can be sustained by local benthic macrofaunal food sources which have a calculated annual productivity of only one-tenth of the rock lobsters requirement. Macrofaunal standing stock proved an insufficient basis for estimating potential food production because it does not take into account recruitment of organisms, particularly barnacles, consumed shortly after settlement. Productivity of barnacle recruitment was measured at $25 \times 10^{3} \mathrm{~kJ} \mathrm{~m}^{-2} \mathrm{yr}^{-1}, 70 \%$ of the calculated annual energetic requirements of the rock lobsters. For much of the year the gut contents of rock lobsters consisted predominantly of barnacle recruits. When barnacle recruitment declined in winter, the rock lobsters turned to other food, including another unexpected source, planktonic mysids. Rock lobsters can clearly use food sources that have until now been ignored by investigators. The rapid turnover of recruits, often undetected in surveys of benthic biomass, is important not only in the present case, but also in the broader context of energy flow through communities.
\end{abstract}

\section{INTRODUCTION}

The South African rock lobster Jasus lalandii is an important subtidal predator (Heydorn 1969, Newman \& Pollock 1974a, Pollock 1979, 1982, 1986) and has the capacity to modify substantially subtidal benthic communities (Branch et al. 1987, Branch \& Barkai 1988). A recent survey of the benthos of 2 near-shore islands on the west coast of South Africa, Marcus $\left(17^{\circ} 58^{\prime} \mathrm{E}\right.$, $33^{\circ} 02^{\prime} \mathrm{S}$ ) and Malgas (17. $\left.55^{\prime} \mathrm{E}, 33^{\circ} 03^{\prime} \mathrm{S}\right)$, has shown that although they have a similar bottom topography and experience fairly comparable physical conditions, their subtidal benthic communities are radically different (Branch \& Barkai 1988, Barkai \& Branch 1988). Marcus Island has prolific beds of the black mussel Choromytilus meridionalis, accompanied by many other species, notably sea urchins, holothurians, whelks and barnacles. In contrast, Malgas Island is dominated by a large population of the rock lobster Jasus lalandii ( $3866 \mathrm{~g}$ wet wt $\mathrm{m}^{-2}$ ), together with a dense seaweed flora. Although the 2 benthic communities appear completely different, we have sug- gested they represent 2 alternative states of the same ecosystem, and that the contrast between the $2 \mathrm{com}$ munities is largely a consequence of the presence or absence of intense predation by rock lobsters (Barkai 1987, Branch et al. 1987, Branch \& Barkai 1988). Many of the benthic species that inhabit the 2 islands are typical of shallow-water communities of the cold Benguela ecosystem (Day 1959, Field et al. 1977, Brown \& Jarman 1978, Field et al. 1980), but the presence of large numbers of rock lobsters at Malgas Island, and their near absence at Marcus Island, seem to be the major reason why these 2 benthic communities differ. One possible explanation for this difference is that, in the past, a combination of factors, such as organic pollution from fish factories, oxygen-deficient water, poaching and construction work on the iron ore jetty in the bay, depleted the population of rock lobsters around Marcus Island (Newman \& Pollock 1973, Christie \& Moldan 1977, Beckley 1981, Barkai 1987, Barkai \& Branch 1988). The 2 benthic communities on the islands may then have developed into 2 different stable states. Saldanha Bay has, however, 
been a rock lobster sanctuary since 1929 (D. E. Pollock pers. comm.) and oxygen levels in the vicinity of the islands have been normal since the introduction in 1979 of measures controlling the method of offloading at local fish factories (Gardner et al. 1983, Barkai 1987. Barkai \& Branch 1988). Despite this, rock lobsters have not colonised Marcus Island in appreciable numbers.

A major question that arises is how the high density of rock lobsters at Malgas Island can be maintained, when the benthic community there almost completely lacks food sources such as mussels and urchins - the accepted, conspicuous prey of rock lobsters (Heydorn 1969, Newman \& Pollock 1969, Griffiths \& Seiderer 1980, Pollock et al. 1982, Pollock 1986).

We sought to answer this question by determining (1) the energetic needs of the rock lobsters, (2) the availability of their accepted food, particularly mussels, and (3) the relationship between available food and diet of the rock lobsters. The findings that resulted from these objectives led to further exploration of unorthodox food sources and, more specifically, to a detailed study of the productivity of freshly recruited organisms in relation to the energetic needs of the rock lobsters.

\section{MATERIALS AND METHODS}

Analysis of gut contents. Samples of gut contents were taken from rock lobsters at Marcus and Malgas Islands quarterly from 1983 to 1986. Samples were limited to a total of 120 ind. $\mathrm{yr}^{-1}$ in accordance with a permit restricting the killing of lobsters. Proventriculj. were separated and fixed in $4 \%$ formalin in seawater before their contents were examined microscopically and identified to species level. The relative abundance of each food item was estimated from the contribution it made to the total volume of each gut $(P$, expressed as $\%)$. This value was then multiplied by the estimated fullness of the gut ( $F$, ranked from 1 to 10$)$, summed for all guts, and divided by the total relative value of all food items from all the gut contents of the sample and expressed as percentage (after Shepherd 1973). ( $\Sigma P F /$ $\Sigma \Sigma P F) 100$.

This analysis is subject to the usual bias that shell remains persist longer than soft parts. Rock lobsters also swallow fragments of shell and exoskeleton (Heydorn 1969, Aiken 1980), presumably to facilitate digestion and intake of calcium after ecdysis. Isolated fragments of shell or exoskeleton were therefore excluded from the analysis.

The thickness of barnacle plates in the rock lobster guts was measured from subsamples. Relatively undamaged plates were selected and measured at their center, to $0.01 \mathrm{~mm}$. A regression relating shell thick- ness to barnacle age was then used to determine the age of the barnacles in the sample.

Rock lobster survival. Rock lobsters were held in pairs of cages $(1.15 \times 1.15 \times 0.33 \mathrm{~m})$ placed at $10 \mathrm{~m}$ depth at each of the islands. Each cage was initially divided into 4 chambers. Two chambers of the cages were left undisturbed to act as controls; the other 2 each contained 2 rock lobsters. The cage mesh $(0.5 \mathrm{~cm} \times 0.5 \mathrm{~cm})$ was small enough to prevent penetration of most macrobenthic species that might serve as prey for the rock lobsters. The condition of these rock lobsters was monitored regularly, as was settlement and growth of benthic species on the cage floor. All observations were done by means of SCUBA with as little interference as possible to the animals.

Barnacle production. Monthly production by recruits of the most abundant barnacle, Notomegabalanus algicola, was monitored on settlement plates. Eight marine ply settlement plates $(25 \mathrm{~cm} \times$ $17.5 \mathrm{~cm}$ ) were coated with glass-reinforced polyester (GRP) and sprayed with fine sea sand and shell fragments to roughen them. Each plate was placed in a container of seawater for $2 \mathrm{wk}$ and then dried on absorbent paper and weighed. The plates were then connected to each other by wire. The lowermost plates were anchored to the sea floor at $10 \mathrm{~m}$ depth and the uppermost plates to a submerged buoy (Fig. la). Four plates were then left in the sea at each island. They were replaced approximately monthly by similar sets of plates over the period 23 November 1984 to 17 December 1985. After removal from the sea, the plates were dried and weighed as above. The biomass of the barnacles was then calculated. To account for other fouling species that had settled, subsamples of these species were cleared off the plate and weighed. Their total weights were calculated, using their percentage cover or total number, and subtracted from the total biomass to obtain the wet weight of barnacles per plate.

Continuous accumulation of barnacles was measured on similar marine ply plates. In this case 32 plates were placed at each island. Approximately every $40 \mathrm{~d}$, 4 plates were removed and the barnacle wet weight calculated as above, while the remaining plates were left in place to permit continued growth and accumulation of barnacles. This experiment began during the season of peak bamacle recruitment and ran for $214 \mathrm{~d}$ from 23 November 1984. It was terminated when a severe storm eliminated the remaining plates.

Growth rate and production of barnacles during the first few weeks after settlement were measured more intensively from 15 November 1985 to 16 January 1986, during the peak season of settlement, on the assumption that over periods of $40 \mathrm{~d}$ or more, the biomass of barnacles might peak and then drop due to intra- 


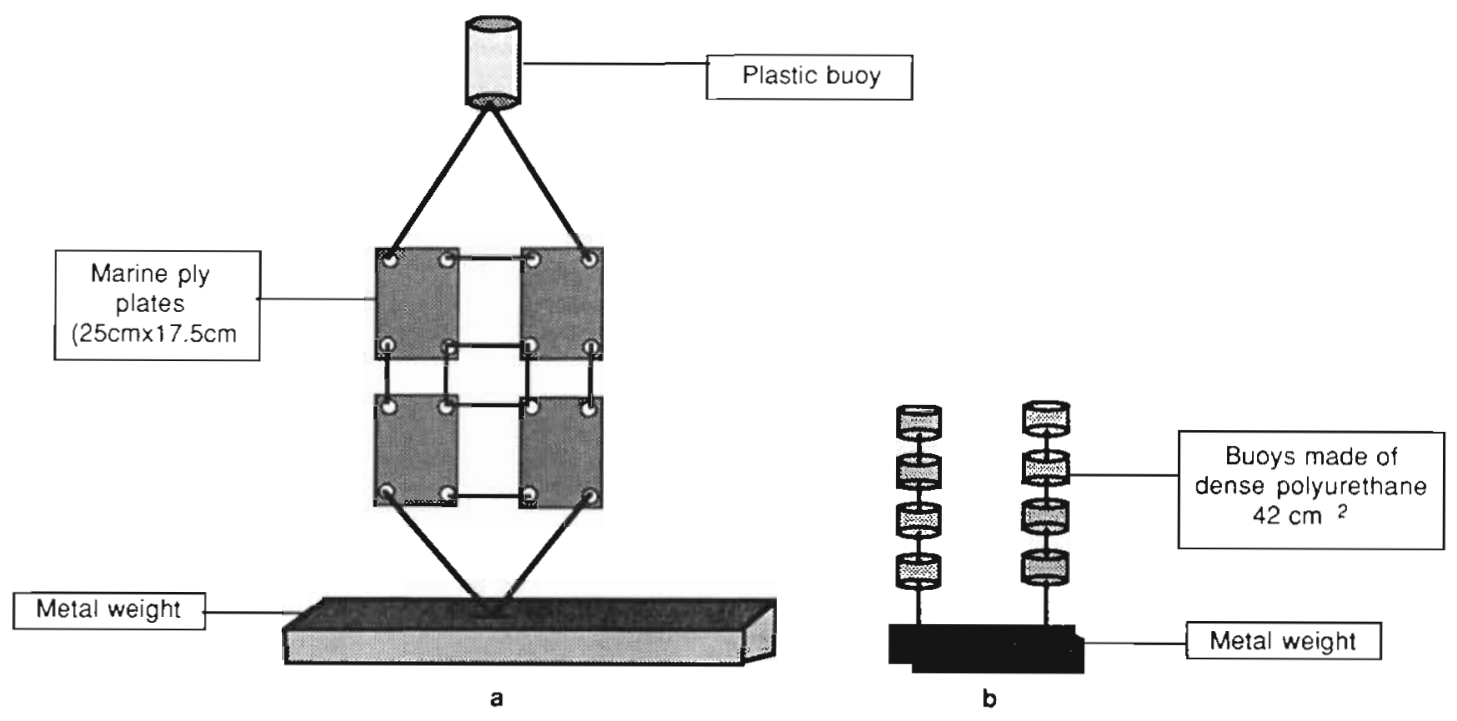

Fig. 1. Arrangement of (a) plates used to record seasonal and cumulative recruitment, and (b) small polyurethane buoys used to determine daily recruitment

specific competition for space. The artificial substratum used for settlement consisted of buoys made of dense polyurethane (fishing net floats) with a surface area of $0.4 \mathrm{~m}^{2}$. Eight groups of 4 buoys each were used. The buoys were placed at $10 \mathrm{~m}$ depth near Marcus Island. They were then monitored at short time intervals ( 2 to $8 \mathrm{~d})$ from the time recruits first appeared until the buoys were completely smothered and the biomass began to drop (after $40 \mathrm{~d}$ ). Subsamples of the barnacles were removed at each interval to allow accurate measurement of shell thickness and length, and some of the buoys were sacrificed each time to accurately measure the biomass. The largest barnacles were measured in order to monitor growth rate of the founder generation only. Subsamples of barnacles of 20 to $40 \mathrm{~d}$ old were dried for $48 \mathrm{~h}$ and their calorific value was established using an SP500 bomb calorimeter.

Mussel production and size distribution. The production of mussel recruits (of both Choromytilus meridionalis and Aulacomya ater) was monitored using the same plates as described for barnacle production. The number of mussels per unit area was counted, subsamples wet-weighed, and the total wet biomass of mussels per plate calculated. Conversions from wet to dry biomass $(1: 0.503)$ and from dry mass to calorific values $(1 \mathrm{~g}=2.87 \mathrm{~kJ})$ were taken from average values for C. meridionalis and A. ater (Field et al. 1980, Griffiths 1981).

A random sample of 187 Aulacomya ater was collected off Malgas Island to determine size distribution. Mean density was based on the average figure obtained from 3 annual benthic samples at Malgas Island (Barkai 1987, Barkai \& Branch 1988).
Biomass, size distribution and sex ratio of Jasus lalandii. A 3 yr average biomass of $J$. lalandii (as calculated by Barkai 1987 and Barkai \& Branch 1988) was used in all calculations. The sex ratio and size distribution were established from the measurements of 1901 randomly collected rock lobsters and represent a specific population structure at the time of the collecting. Male and female size distributions were converted to numbers of each size group per $\mathrm{m}^{2}$. Dry biomass (g) was calculated from carapace length ( $\mathrm{L}, \mathrm{mm}$ ) using Zoutendyk's (1988a) equation: Dry mass = $0.0000274 \mathrm{~L}^{2.877}$.

Fecundity and egg production of Jasus lalandii. Female rock lobsters (153 ind.) 'in berry' were collected from Malgas Island in 20 September 1986, close to the beginning of the reproductive season (Heydorn 1969). Their carapace sizes and wet weights were recorded and the eggs of 29 females dried for $72 \mathrm{~h}$ at $60^{\circ} \mathrm{C}$ and weighed (using the methods of Beyers \& Goosen 1987). The calorific value of the eggs was measured using a CP500 bomb calorimeter.

Energy budget for Jasus lalandii. Energy requirement of the J. lalandii at Malgas Island was calculated, based on (1) respiration, which has been measured for male $J$. lalandii (we assumed similar respiration rate for both sexes) in the laboratory (P. Zoutendyk pers. comm.); (2) reproduction, based on the calorific value of eggs, seasonal reproductive cycles and the relation between body size and egg production (see above); (3) various figures for growth rate (reviewed in Wickens 1985): (4) cost of moulting (Zoutendyk 1988b). In calculating the energetic cost of growth and moulting, the following conversions were employed between 
carapace length ( $\mathrm{L}$, in $\mathrm{mm}$ ) and wet mass ( $\mathrm{W}$, in $\mathrm{g}$ ) (Heydorn 1969) and between exuvial dry mass (DME, in g) and carapace length (Zoutendyk 1988b):

$$
\begin{aligned}
W & =\left(\mathrm{L}^{2.894}\right) / 1215.865 \text { (for males) } \\
W & =\left(\mathrm{L}^{2.973}\right) / 1600.795 \text { (for females) } \\
D M E & =\left(\mathrm{L}^{3.405}\right) 0.0000334
\end{aligned}
$$

(5) Nitrogen excretion in form of urea $\left(10.5 \mathrm{~kJ} \mathrm{~g}^{-1}\right)$ and ammonia $\left(20.5 \mathrm{~kJ} \mathrm{~g}^{-1}\right.$ ) (Brafield \& Llewellyn 1982) is only $0.68 \%$ of the total $J$. lalandii energy intake (Zoutendyk 1988c, and pers. comm.). This figure was added to the total calculated energy needs of the rock lobster population at Malgas Island.

The energy content of Jasus lalandii is $14.53 \mathrm{~kJ} \mathrm{~g}^{-1}$ dry mass (Field et al. 1980) and energy content of $J$. lalandii exuviae is $5.95 \mathrm{~kJ} \mathrm{~g}^{-1}$ dry mass (Zoutendyk 1988 b). An additional $4 \%$ was added to the calculated or measured energetic costs of growth moulting and reproduction, to allow for the cost of synthesis (Brafield \& Llewellyn 1982).

\section{RESULTS AND DISCUSSION}

\section{Rock lobster standing stocks at Marcus and Malgas Islands}

During 1983 to 1985 both Marcus and Malgas Islands were sampled annually to determine the biomass of all benthic species, including Jasus lalandii (Branch et al. 1987, Branch \& Barkai 1988). J. lalandii was seldom recorded at Marcus Island, although very small individuals (of 20 to $30 \mathrm{~mm}$ carapace size) were observed in deeper water, occasionally in relatively large numbers, with groups of about 50 to 100 individuals hiding in holes amongst the mussels. Larger rock lobsters (100 to $120 \mathrm{~mm}$ ) were seldom seen at Marcus Island, and then only in very small numbers ( 1 to 5 individuals per dive) and never on the mussel beds. In contrast, Malgas Island had a large rock lobster population with a mean density of $10.17( \pm 7.24 \mathrm{SD}) \mathrm{m}^{-2}$. In some cases more than $600 \mathrm{~m}^{-2}$ were counted. Even the mean figure is very high when compared to some of the richer rock lobster grounds on the South African west coast (e.g. an average of $0.81 \mathrm{~m}^{-2}$ with maxima of $2.19,2.50,2.37$ and $1.9 \mathrm{~m}^{-2}$ at different depths and stations off Robben Island near Cape Town; Pollock 1979).

Juvenile Jasus lalandii are usually found in shallow water, aggregating in large numbers in deep crevices (Pollock 1979). After reaching a carapace size of 50 to $60 \mathrm{~mm}, J$. lalandii normally moves to deeper water and disperses over a larger area (Heydorn 1969, Newman \& Pollock 1974a, Pollock 1979). Possibly the narrowness of the rock bottom surrounding Malgas Island and its isolation from adjacent rocky areas by the surrounding sandy bottom may stop or slow this dynamic process.

The sex ratio of Jasus lalandil at Malgas Island was approximately 3 males to 7 females, a significant departure from equality (chi-squared analysis, $p<0.001, n=1901$ ). The sex ratio fluctuated seasonally and varied at different depths. This is in keeping with other observations: in shallow water the number of females is normally larger than that of males. For example females constituted $79 \%$ of the population at Elands Bay at $11 \mathrm{~m}$ depth and $95 \%$ south of Elands Bay at $9 \mathrm{~m}$ depth (Pollock 1982). At Robben Island females made up $76.3,75.3$ and $72.1 \%$ of the population on different dates (Heydorn 1969). Shallow-water populations are also usually characterised by high density and a small average carapace length. (Pollock 1982).

The carapace sizes of rock lobsters at Malgas Island ranged between 58 and $97 \mathrm{~mm}$ for females (mean = $75.42 \mathrm{~mm}, \mathrm{SD}=8.53 \mathrm{~mm}$ ) and between 71 and $134 \mathrm{~mm}$ for males $($ mean $=99.44 \mathrm{~mm}, \mathrm{SD}=16.64 \mathrm{~mm})$. The overall size distribution is shown in Fig. 2a. Almost no individuals under these size ranges were ever observed at Malgas Island, excluding very small specimens found in experimental cages (Barkai 1987). The large mean size and the high density of the population at Malgas Island, together with the fact that the proportion of females is slightly lower than normal, suggest that this population combines features normally typical of either shallow or deep-water rock lobster populations (Heydorn 1969, Pollock 1979, Pollock et al. 1982, Pollock 1986). This may reflect the fact that the rock lobsters cannot move into deeper waters.

The mean (dry) biomass of rock lobsters at Malgas Island was calculated (from the regressions given in 'Materials and Methods') to be $1094 \mathrm{~g} \mathrm{~m}^{-2}$.

\section{Energy requirements of the rock lobster population at Malgas Island}

Growth and moulting

All growth-rate data available for Jasus lalandii on the South African west coast have been reviewed by Wickens (1985). Wickens divided the data into 2 groups viz, those showing slow and fast growth, and also gave an overall growth rate. These data are summarized in Table 1 together with more specific information on growth rates in Saldanha Bay and at nearby Dassen Island. No data on growth rates are available for rock lobsters at Malgas Island specifically. However Beyers \& Goosen (1987) have shown that in areas with fast growth rates sexual maturity is reached at a large carapace size and fecundity is high. Among the sites they worked at, Dassen and Robben Islands are known 
Fig. 2. Aulacomya ater and Jasus lalandii. (a) Size distribution of ribbed mussel (shell length) and rock lobster (carapace length) at Malgas Island. (b) Energy available to $J$. lalandii from standing stocks of A. ater at Malgas Island, calculated from critical prey size equation of Griffiths \& Seiderer (1980), Lm = $-11.41+1.04 \mathrm{Lr}$, where Lm $=$ critical length of mussel $(\mathrm{mm})$ and $\mathrm{Lr}=$ carapace length of lobster $(\mathrm{mm})$, and an equation relating size of $A$. ater to its calorific value (Griffiths \& King 1979)

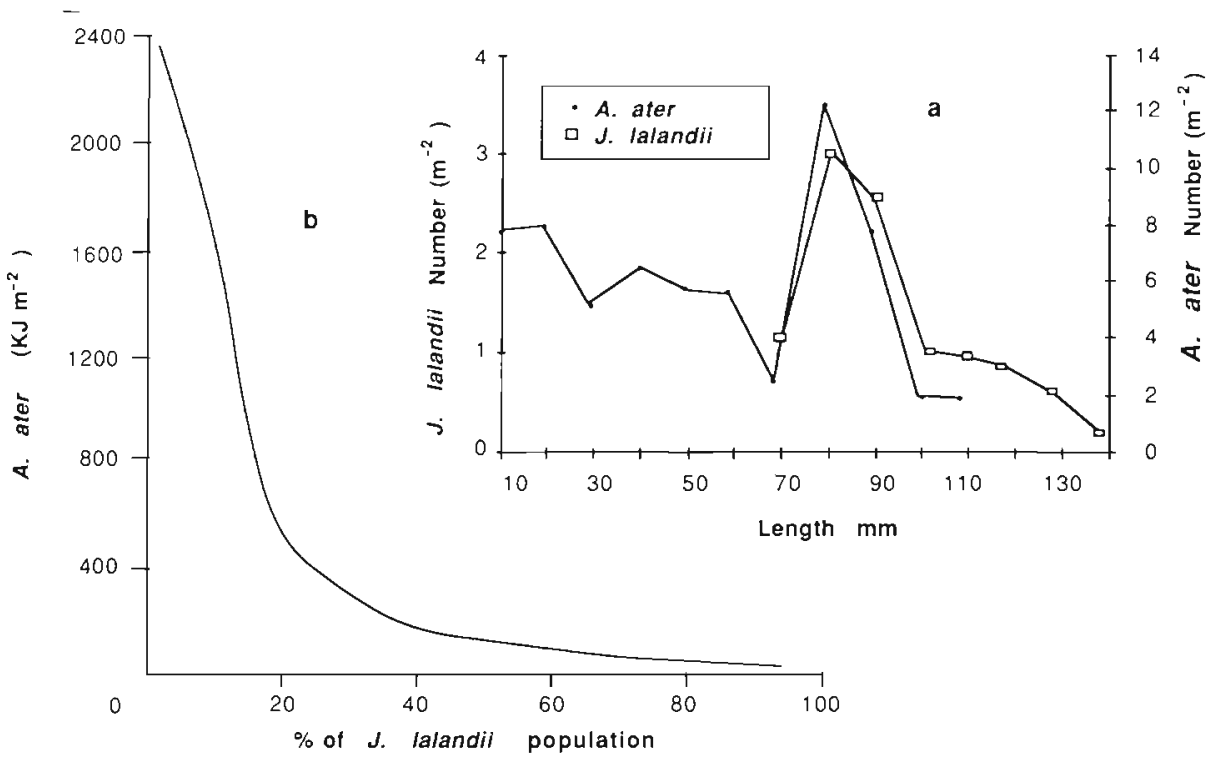

Table 1. Jasus lalandii. Annual growth increment (carapace length $\mathrm{mm}^{-1} \mathrm{r}^{-1}$ ) of males and females from different localities and authors

\begin{tabular}{|c|c|c|c|}
\hline \multirow[t]{2}{*}{ Locality } & \multicolumn{2}{|c|}{ Growth rate $\left(\mathrm{mm} \mathrm{yr}^{-1}\right)$} & \multirow[t]{2}{*}{ Source } \\
\hline & Males & Females & \\
\hline \multicolumn{4}{|c|}{ West coast of S. Africa } \\
\hline Slow & 2.8 & 0.9 & Wickens (1985) \\
\hline Fast & 4.8 & 1.5 & Wickens (1985) \\
\hline Overall mean & 3.8 & 1.3 & Wickens (1985) \\
\hline Saldanha Bay & 4.4 & 0.9 & Pollock et al. (1982) \\
\hline Dassen Island & 4.4 & 0.6 & Newman \& Pollock (1974a) \\
\hline
\end{tabular}

to support the fastest growing $J$. lalandii on the west coast (Newman \& Pollock 1974a, Wickens 1985, Beyers $\&$ Goosen 1987). We repeated observations made by Beyers \& Goosen (1987) at Malgas Island, and confirmed that females mature at a large size $(77 \%$ of females in berry were larger than $73 \mathrm{~mm}$ ) and have a high fecundity (Fig. 3). Furthermore, the relatively large mean sizes of male and female $J$. lalandii at Malgas Island (99.44 and $75.42 \mathrm{~mm}$ respectively) are close to the mean sizes found at Robben Island (Heydorn 1969, Pollock 1979). Several lines of evidence therefore suggest that the growth rate at Malgas Island is very fast. Consequently the fast growth rate given by Wickens (1985) was assumed as an estimation on the energy requirement for growth of the Malgas rock lobsters. (Even if this assumption is incorrect, it is conservative because, if anything, it will overestimate the energetic needs for growth). To calculate the energy required for growth, annual increments in size were converted to biomass and then $\mathrm{kJ}$, using the conversions and assumptions given in 'Materials and Methods'
The total energy requirement for growth of male and female Jasus lalandii at Malgas Island amounted to $3.94 \mathrm{~kJ} \mathrm{~m}^{-2} \mathrm{~d}^{-1}$, giving an annual requirement of $1441 \mathrm{~kJ} \mathrm{~m}^{-2}$ (Table 2).

Total moulting cost of Jasus lalandii (1 moulting $\mathrm{yr}^{-1}$ for adult rock lobsters; Heydorn 1969) at Malgas Island, using the conversions given in Materials and Methods', amounted to $1863 \mathrm{~kJ} \mathrm{~m}^{-2} \mathrm{yr}^{-1}$ (Table 2).

\section{Reproduction}

Energy requirements for reproduction were calculated for female Jasus lalandii only, on the assumption that energetic output for reproduction is minimal in males. This presumption has previously been advanced as the reason why male rock lobsters have faster growth rates than females and may also explain their much greater average size (Beyers \& Goosen 1987). It is assumed that in the female most of the energy input into reproduction is in the form of the yolky eggs, their protoplasmic membranes and the 


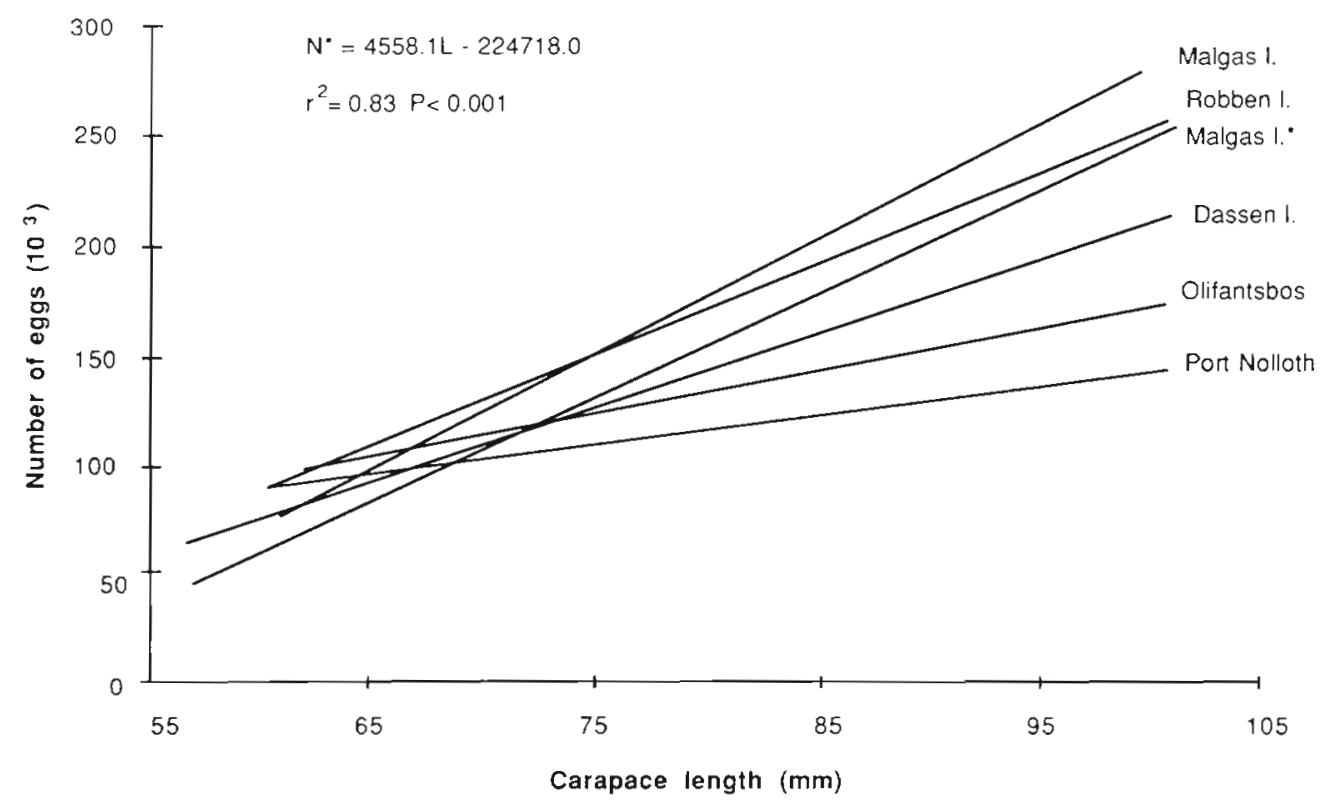

Fig. 3. Jasus lalandii. Comparative regression lines describing the relation between carapace length $(L$, in $\mathrm{mm}$ ) and number of eggs (N) carried by females at different localities (data from Beyers \& Goosen 1987 except for the asterisked line which is original)

Table 2. Jasus lalandii. Summary of the energy requirement of the population $\left(\mathrm{m}=\right.$ male, $\mathrm{f}=$ female) at Malgas Island $\left(\mathrm{kJ} \mathrm{m}^{-2}\right.$ $\mathrm{d}^{-1}$ ). Aquarium respiration values were multiplied by a factor of 1.45 to allow for nocturnal activity (Winget 1969 ). Four \% has been added to the total energy costs of reproduction, moulting and growth to allow for cost of synthesis. Ovarian development is assumed to take $213 \mathrm{~d}$ (see text). Energy cost of moulting was divided by 365 to give a daily requirement, although moulting occurs only once a year among rock lobsters of the sizes found at Malgas Island

\begin{tabular}{|c|c|c|c|c|c|c|c|c|}
\hline \multirow{2}{*}{$\begin{array}{l}\text { Carapace } \\
\text { size }(\mathrm{mm})\end{array}$} & \multicolumn{2}{|c|}{ Number $\mathrm{m}^{-2}$} & \multirow{2}{*}{$\begin{array}{c}\text { Respiration } \\
m+\mathrm{f}\end{array}$} & \multirow{2}{*}{$\begin{array}{c}\text { Reproduction } \\
\text { f only }\end{array}$} & \multirow{2}{*}{$\begin{array}{l}\text { Moulting } \\
\mathrm{m}+\mathrm{f}\end{array}$} & \multicolumn{3}{|c|}{ Growth } \\
\hline & $\mathrm{m}$ & $f$ & & & & Slow & Fast & Overall \\
\hline 62.5 & 0.00 & 0.39 & 0.65 & 0.14 & 0.06 & 0.03 & 0.04 & 0.04 \\
\hline 67.5 & 0.00 & 0.83 & 1.64 & 0.37 & 0.17 & 0.06 & 0.11 & 0.09 \\
\hline 72.5 & 0.07 & 1.57 & 3.77 & 0.82 & 0.66 & 0.15 & 0.26 & 0.22 \\
\hline 77.5 & 0.24 & 1.67 & 5.22 & 0.99 & 0.59 & 0.24 & 0.40 & 0.34 \\
\hline 82.5 & 0.28 & 1.03 & 4.14 & 0.69 & 0.49 & 0.21 & 0.36 & 0.30 \\
\hline 87.5 & 0.38 & 0.99 & 4.85 & 0.71 & 0.61 & 0.26 & 0.45 & 0.37 \\
\hline 92.5 & 0.25 & 0.38 & 2.34 & 0.27 & 0.33 & 0.14 & 0.25 & 0.20 \\
\hline 97.5 & 0.15 & 0.26 & 1.67 & 0.23 & 0.25 & 0.09 & 0.1 .5 & 0.12 \\
\hline 102.5 & 0.24 & 0.00 & 1.25 & - & 0.17 & 0.12 & 0.21 & 0.16 \\
\hline 107.5 & 0.39 & 0.00 & 2.22 & - & 0.33 & 0.21 & 0.36 & 0.28 \\
\hline 112.5 & 0.31 & 0.00 & 2.01 & - & 0.30 & 0.18 & 0.32 & 0.25 \\
\hline 117.5 & 0.26 & 0.00 & 1.72 & - & 0.28 & 0.15 & 0.27 & 0.21 \\
\hline 122.5 & 0.21 & 0.00 & 1.66 & - & 0.26 & 0.15 & 0.25 & 0.20 \\
\hline 127.5 & 0.17 & 0.00 & 1.47 & - & 0.24 & 0.13 & 0.22 & 0.17 \\
\hline 1325 & 0.10 & 0.00 & 0.95 & - & 0.16 & 0.08 & 0.14 & 0.11 \\
\hline Total & 3.05 & 7.12 & 51.56 & 439 & 5.10 & 2.20 & 3.94 & 3.06 \\
\hline
\end{tabular}

funiculi that attach the eggs to the pleopods (see Silberbauer 1971 for details of the reproductive system of J. lalandii). Fig. 4 shows the regression of calorific value of the eggs against carapace size, from which it was possible to calculate the energy expended on egg production by the entire population at Malgas (Table 2).

An average daily value of $4.39 \mathrm{~kJ} \mathrm{~m}^{-2}$ was calculated for the whole population. The ovary develops over a period of about $213 \mathrm{~d}$ per year (Fig. 5), and on this basis the annual requirement will be $935 \mathrm{~kJ} \mathrm{~m}^{-2}$. This is about $4 \%$ of the total energy requirement of Jasus lalandii and can be compared with an average of $4.3 \%$ absorbed energy required for reproduction as calculated by Brafield \& Llewellyn (1982) using the data of Conover (1978) for 20 aquatic invertebrates. 


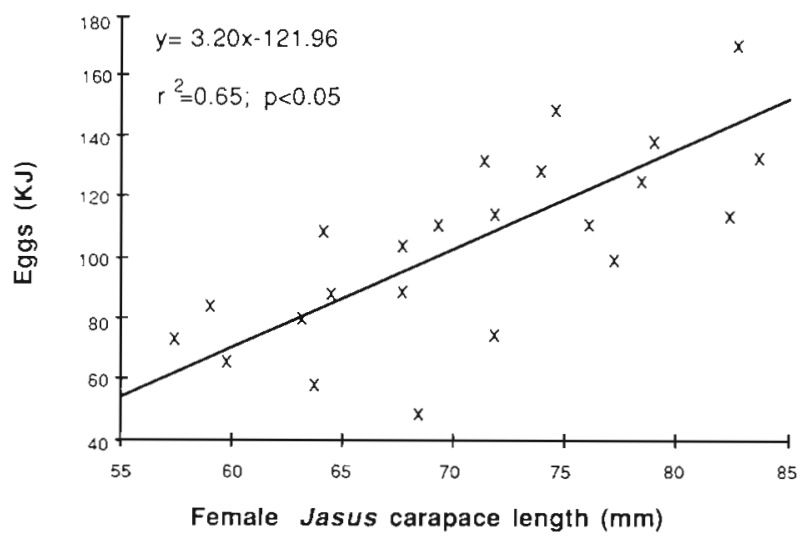

Fig. 4. Jasus lalandii. Total calorific value of eggs carried by females of different carapace lengths at Malgas Island

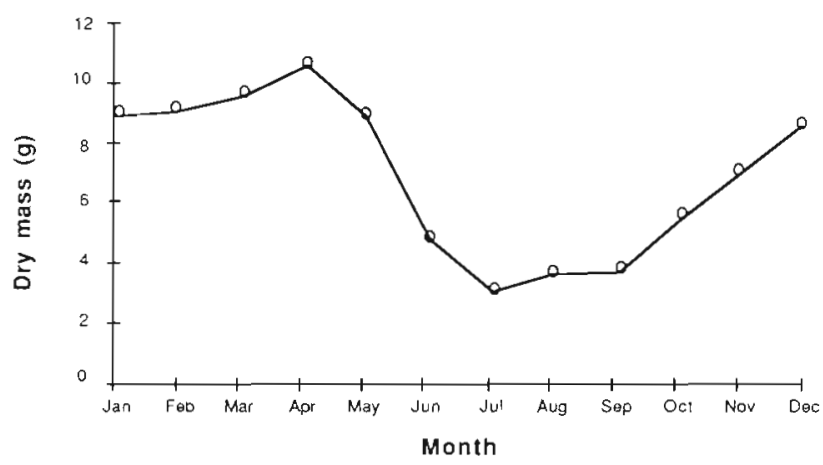

Fig. 5. Jasus lalandii. Average monthly ovarian dry weights of a female ( 70 to $90 \mathrm{~mm}$ carapace length), calculated from data obtained from Heydorn (1969)

\section{Respiration}

The respiration rate of Jasus lalandii has been measured for males of different size classes held at different temperatures ( $P$. Zoutendyk pers. comm.). Mean sea temperature at Malgas Island is $12^{\circ} \mathrm{C}$ (Barkai 1987) and mean monthly sea temperatures in the vicinity vary by only $4{ }^{\circ} \mathrm{C}$ (Taunton-Clark \& Kamstra 1988). Consequently the metabolic costs were calculated for respiration at $12^{\circ} \mathrm{C}: \mathrm{R}=1.13\left(10^{-4} \mathrm{~L}^{3.32}\right)$, where $\mathrm{R}=$ respiration rate in $\mathrm{kJ} \mathrm{d}^{-1}$, and $\mathrm{L}=$ carapace length in $\mathrm{mm}$. The metabolic energy requirements of the J. lalandii population could then be calculated from the size distribution (Table 2).

The total calculated energy consumed by respiration is $51.56 \mathrm{~kJ} \mathrm{~m}^{-2} \mathrm{~d}^{-1}$ and the annual rate $18820 \mathrm{~kJ} \mathrm{~m}^{-2}$, or an average of $3.92 \mathrm{~kJ}$ per $300 \mathrm{~g}$ individual $\mathrm{d}^{-1}$, equivalent to $81 \%$ of the total daily energy requirement of Jasus lalandiu (Table 2). By comparison Winget (1969) obtained values of 6.28 and $10.46 \mathrm{~kJ} \mathrm{~d}^{-1}$, in winter and summer respectively, for oxygen consumption by $300 \mathrm{~g}$ spiny lobsters Panulirus interruptus, and McLeese
$(1964,1968)$ recorded 2.53 and $7.47 \mathrm{~kJ} \mathrm{~d}^{-1}$ at $5^{\circ} \mathrm{C}$ and $21^{\circ} \mathrm{C}$ respectively for Homarus americanus, Conover (1978) calculated the average metabolic maintenance cost for intertidal and subtidal invertebrates to be ca $77 \%$ of total energetic needs.

\section{Total energy requirements for Jasus lalandii}

By summing the above figures for metabolism (R), nitrogen excretion (U, see 'Materials and Methods'), moulting (M), growth (Pg), and reproduction (Pr), the annual absorbed energy required by an average of 10.17 ind. $\mathrm{m}^{-2}$ is:

$$
\begin{gathered}
\mathrm{R}+\mathrm{U}+\mathrm{M}+\mathrm{Pg}+\mathrm{Pr}=18820+1863+157+1441+935= \\
23215 \mathrm{~kJ} \mathrm{~m}^{-2} \mathrm{yr}^{-1}
\end{gathered}
$$

Jasus lalandii loses about $20 \%$ of its food due to 'messy feeding' and has an absorption efficiency value of $79.5 \%$ (Zoutendyk 1988d), leaving $64 \%$ net gain from the food. Thus the rock lobsters must consume:

$$
23215 \mathrm{~kJ} \mathrm{~m}^{-2} \mathrm{yr}^{-1}(100 / 64)=36273 \mathrm{~kJ} \mathrm{~m}^{-2} \mathrm{yr}^{-1}
$$

As an independent assessment of the validity of this calculation, comparison can be made with Zoutendyk's (1988d) measurement of $479 \mathrm{mgC}$ dry mass ${ }^{-1} \mathrm{yr}^{-1}$ for the mass-specific consumption of captive Jasus lalandii fed on mussels. To this value $20 \%$ must be added to allow for energy lost due to messy feeding (Zoutendyk 1988d). Zoutendyk (1988d) also provides a conversion factor of $0.3873: 1$ for carbon: mussel dry mass, and an energy value of $18.9 \mathrm{~kJ} \mathrm{~g}^{-1}$ dry mass for mussel flesh. On this basis the rock lobsters at Malgas Island (with a dry biomass of $1094 \mathrm{~g} \mathrm{~m}^{-2}$ ) should consume 30687 $\mathrm{kJ} \mathrm{m}^{-2}$. This is in fairly close agreement with our calculation of $36273 \mathrm{~kJ} \mathrm{~m}^{-2} \mathrm{yr}^{-1}$ based on the rock lobsters needs.

\section{Food sources at Marcus and Malgas Islands}

Standing stocks (in $\mathrm{kJ} \mathrm{m}^{-2}$ ) of species known to be preyed upon by rock lobster for both Marcus and Malgas Islands are summarized in Table 3 . From the data it is evident that the macrofaunal food resources at Marcus Island could have provided about 16 times more energy for Jasus lalandii than those at Malgas Island. Choromytilus meridionalis was the main energy source $(88 \%)$ at Marcus Island, while at Malgas Island, Aulacomya ater was more important. The total standing calorific value of all the benthic prey at Malgas Island was very small, being only $9 \%$ of the calculated annual requirement of $J$. lalandii. A. ater, which provided $78 \%$ of this standing stock, has often been recorded or considered as a major food source for rock 
Table 3. Calorific value of standing stocks of macrofaunal benthic taxa at Marcus and Malgas Islands, compared to energy available from recruits

\begin{tabular}{|c|c|c|c|c|}
\hline \multirow[b]{2}{*}{ Taxon } & \multicolumn{2}{|c|}{ Standing stock $\left(\mathrm{kJ} \mathrm{m}^{-2}\right)$} & \multicolumn{2}{|c|}{ Recruit species } \\
\hline & Marcus I. & Malgas I. & Taxon & $\begin{array}{l}\text { Energy value } \\
\left(\mathrm{kJ} \mathrm{m}^{-2} \mathrm{yr}^{-1}\right)\end{array}$ \\
\hline Porifera $^{a}$ & 78 & 165 & Barnacles & 25265 \\
\hline Polychaeta & 332 & 27 & Mussels & 295 \\
\hline Cirripedia & 170 & 19 & & \\
\hline Small crustaceans & 97 & 30 & & \\
\hline Other crustaceans & 166 & 0 & & \\
\hline Choromytilus meridionalis & 42748 & 0 & & \\
\hline Aulacomya ater & 26 & 2386 & & \\
\hline Burnupena spp. & 4203 & 420 & & \\
\hline Other gastropods & 218 & 0 & & \\
\hline Parechinus angulosus & 378 & 0 & & \\
\hline Total: & 48416 & 3049 & & 25560 \\
\hline
\end{tabular}

lobsters (Heydorn 1969, Pollock 1979, 1986, Griffiths \& Seiderer 1980). Indeed, the availability of mussels is, in many cases, considered the main factor limiting the growth rate and population size of J. lalandii. For instance, Newman \& Pollock (1974a) suggested that a correlation exists between benthic biomass (mostly $A$. ater) and rock lobster growth rates. However, not all $A$. ater are accessible to $J$. lalandii. When comparing the size composition of $J$. lalandii and $A$. ater at Robben Island, Pollock (1979) noted that $J$. lalandii are restricted to feeding only on mussels (Aulacomya ater) smaller than $60 \mathrm{~mm}$ long', which constituted only $20 \%$ of the total mussel biomass. Griffiths \& Seiderer (1980) found that for each size class of rock lobster there is a maximum critical size of $A$. ater above which the rock lobsters cannot prey on the mussels.

Griffiths \& King (1979) calculated the production: biomass ratio (P/B) of Aulacomya ater as 1.13 . Using this figure, and the mean annual standing stock, 2386 $\mathrm{kJ} \mathrm{m}^{-2}$, the annual production of $A$, ater at Malgas Island can be estimated at $2696 \mathrm{~kJ} \mathrm{~m}^{-2} \mathrm{yr}^{-1}$. This is only $8 \%$ of the calculated minimal annual energy requirement of Jasus lalandii at Malgas Island. Furthermore, given the size-frequency of $A$. ater at Malgas Island (Fig. 2a), $83 \%$ of the A. ater standing stock at Malgas Island is in the form of mussels above the critical size accessible to $80 \%$ of the rock lobsters (Fig. 2b), which means that the standing stock of $A$. ater at Malgas Island can supply only about $1 \%$ of the annual energy requirements for most of the rock lobster population. One other factor influences the availability of $A$. ater to $J$ lalandii: mussel recruits and individuals small enough to be eaten were almost all found either in inaccessible places (in kelp holdfasts or under boulders), or within clumps of mussels, amongst and under very large individuals. Although this phenomenon was not quantified, it was clear that it further reduced the availability of small A. ater to rock lobsters. Taking all these factors into account, it is obvious that the standing stock of $A$. ater plays an insignificant role in relation to the total energy requirements of the large population of J. Ialandii at Malgas Island.

\section{Analyses of Jasus lalandii gut contents}

Gut contents were sampled seasonally from rock lobsters at both islands between 1983 and 1986 (Fig. 6). At Marcus Island rock lobsters were scarce and occurred only at the periphery of the mussel beds, where they fed throughout the year on common benthic macrofaunal species, particularly sea urchins Parechinus angulosus, black mussels Choromytilus meridionalis, barnacles, small molluscs and crustaceans. This diet corresponded with the benthos that was locally available, and accords with previously published information on the diet of rock lobsters (Heydorn 1969, Newman \& Pollock 1974a, Pollock 1979, 1982, Griffiths \& Seiderer 1980). The relatively large proportions of barnacles Notomegabalanus algicola in the summer (32\%) and autumn (14\%) gut samples were unexpected, and are discussed in more detail below.

At Malgas Island the rock lobsters, not surprisingly, had a completely different diet. In February and November (summer and late spring) the gut contents were dominated by tiny fragments of the barnacle Notomegabalanus algicola (60 and $67 \%$ respectively). Additional material included small amounts of rock lobster exuvia and pieces of Aulacomya ater shell. In April (autumn) more than $50 \%$ of the gut contents 


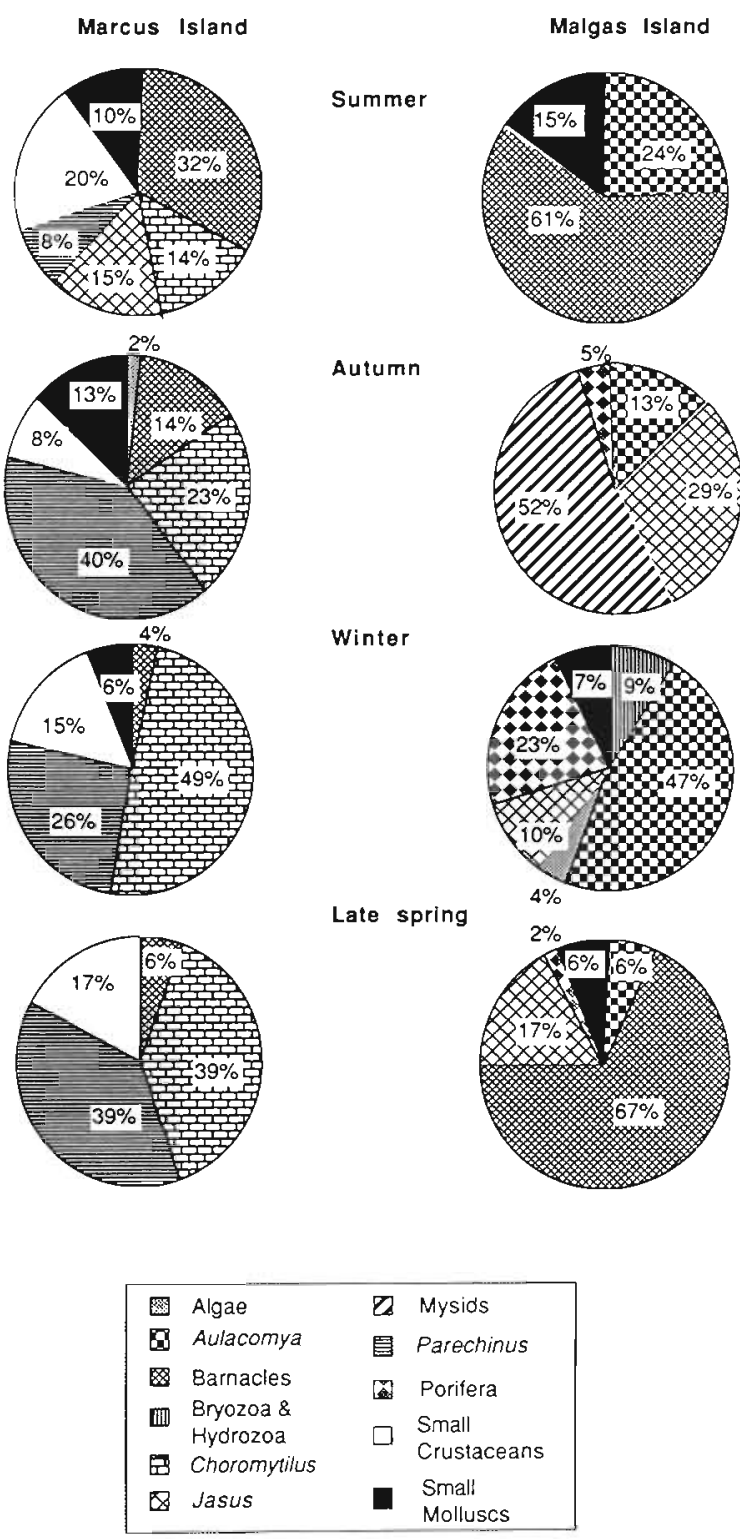

Fig. 6. Jasus lalandii. Relative volumes of different prey groups in the gut contents of rock lobsters (of all sizes) from

Marcus and Malgas Islands, at different times of year

comprised planktonic mysids Mysidopsis schultzei, while $29 \%$ consisted of hard remains of Jasus lalandii, evidencing cannibalism. In August (winter) the diet was more diverse and included $A$. ater shell fragments $(47 \%)$ and poriferan remains $(23 \%)$, which were identifiable by the presence of spicules in the proventriculus. In addition to these major components, the gut contents of rock lobsters from both islands contained lesser amounts of small crustaceans, small bivalves and gastropods, and those from Malgas Island also included fragments of algae, bryozoans and hydrozoans. These components occurred in most of the gut samples throughout the year and were a permanent feature of the diet, although some of them may have been inadvertently consumed while the rock lobsters were feeding on other prey.

Diet changed with the size of the rock lobsters. At Marcus the black mussel Choromytilus meridionalis became increasingly important in the diet of larger rock lobsters, while the urchin Parechinus angulosus was of greater importance to small individuals (Fig. 7). At Malgas Island though, smaller rock lobsters fed on barnacles, mysids, small molluscs and, to a certain extent, on algae and Porifera, but Aulacomya ater progressively dominated the diets of the larger size groups, which also showed a greater degree of cannibalism. This pattern of cannibalism is similar to that observed by Berry (1971) for the Natal spiny lobster Panulirus homarus.

To summarize, at Marcus Island where prey species were abundant, the rock lobsters fed predominantly on two of the most common macrofaunal species there, Parechinus angulosus and Choromytilus meridionalis. But at Malgas Island, where conventional food resources were scarce, they fed on unusual species and the diet was strongly influenced by seasonal fluctuations in prey availability. One surprise was that barnacles played a major role in the diet of Jasus lalandii at Malgas Island, even although they were never detected when the macrobenthos was sampled there. Berry (1971) has reported that barnacles are a significant component of the diet of juvenile Panulirus homarus, but they have never been considered an important food source for J. lalandii.

Cannibalism was more frequent at Malgas Island than in other areas where food is abundant (Heydorn 1969). Under laboratory conditions high densities tend to stimulate cannibalism, particularly of freshly moulted lobsters (Atema \& Cobb 1980). Conversely, cannibalism appears to be absent in areas with low population densities (Atema \& Cobb 1980). The majority of rock lobster remains in the gut samples from Malgas Island were recorded in April and August, which coincides with the female moulting season, but is slightly early for the male moulting season (Heydorn 1969, Newman \& Pollock 1971, Pollock 1982, 1986). Shortage of food, high population density and moulting during the winter season (April to September) may stimulate cannibalism at Malgas Island during that time of year.

\section{Productivity of barnacles}

As discussed above, the barnacle Notomegabalanus algicola occurred in large quantities in gut samples taken from rock lobsters during certain seasons at Malgas Island. However, very few barnacles were 


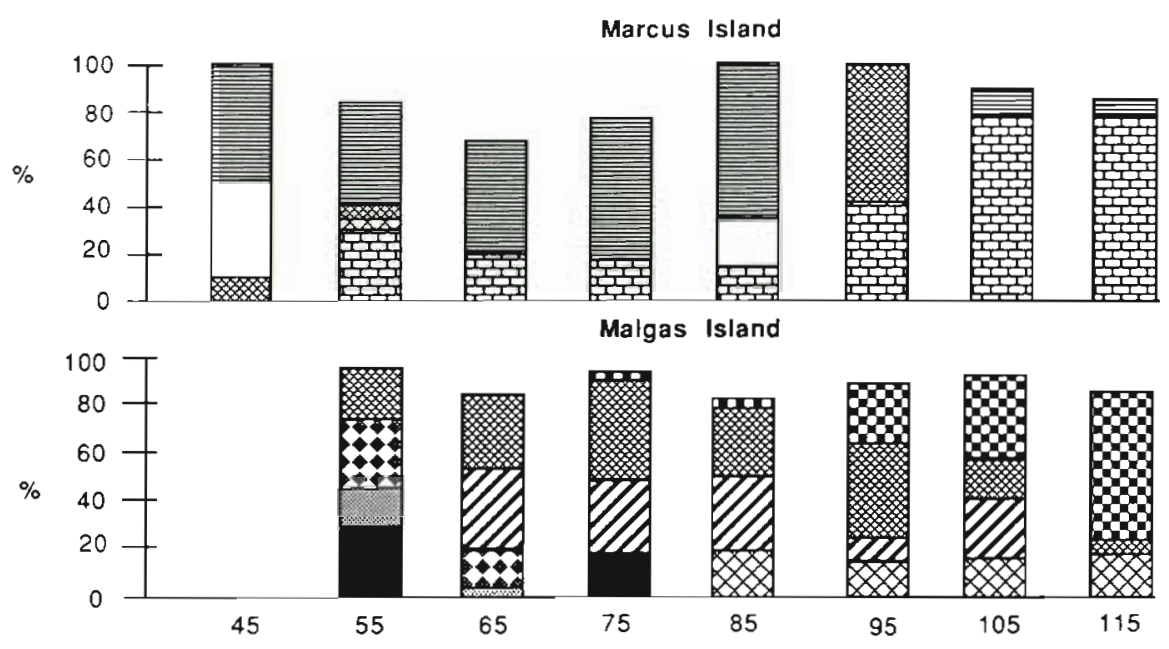

Marcus Island

\begin{tabular}{|l|}
\hline$\equiv$ Parechinus \\
$\square$ Jasus \\
$\square$ Small \\
crustaceans \\
$\square$ Choromytilus \\
Barnacles
\end{tabular}

Fig. 7. Jasus lalandii. Relative abundance (on a weighted scale of stomach fullness) of different prey species in the guts of rock lobsters of different sizes. Minor prey items have been omitted, consequently columns do not necessarily equal $100 \%$

Malgas Island

\begin{tabular}{|ll|}
\hline Algae \\
Porifera \\
$\square$ & Jasus \\
$\square$ & Mysids \\
$\square$ & Aulacomya \\
Barnacles \\
Small \\
molluscs \\
\hline
\end{tabular}

observed on exposed substrata during the 3 annual surveys of the benthic biomass (Barkai 1987, Barkai \& Branch 1988), although they settled densely on floating objects. This suggests that the rock lobsters prey on newly recruited barnacles with such rapidity that the barnacle population at Malgas Island is never capable of establishing itself. The question arises whether these tiny cirripedes, whose bodies consist mostly of undigestible calcareous shell, are capable of contributing a significant amount of energy towards the needs of the dense rock lobster population.

Recruitment of Notomegabalanus algicola was distinctly seasonal with peak settlement occurring in December and January, when a maximum biomass of $4900 \mathrm{~g} \mathrm{~m}^{-2}$ (wet weight) was recorded on the experimental plates (Fig. 8). Recruitment then fel. until June, when no barnacle recrujtment was recorded. As spring approached, recruitment again increased (Fig. 8). On the plates that were continuously monitored to quantify the cumulative effect of successive settlement and to estimate production, barnacle biomass initially rose and then dropped sharply after about $40 \mathrm{~d}$, once the settlement plates had been completely covered. The biomass continued to decline over the 7 mo that the plates were monitored (Fig. 9a). Successive waves of recruitment smothered the first colonisers, so that the overcrowded barnacles became loosely attached to the

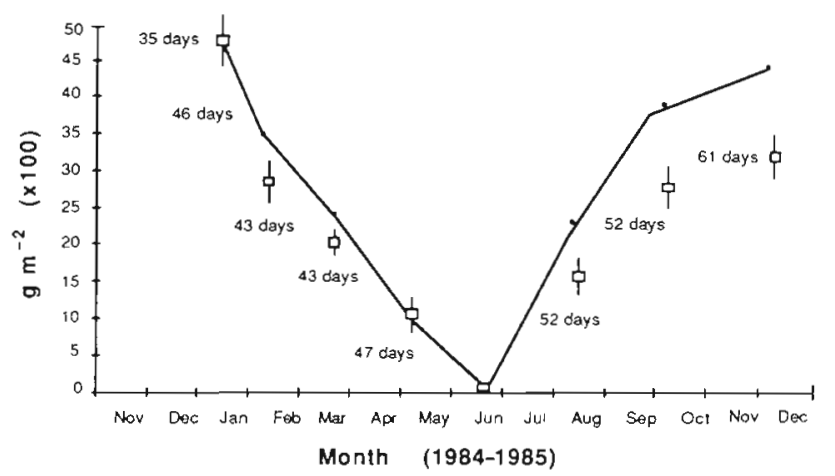

Fig. 8. Notomegabalanus algicola. Monthly biomass (wet weight $\mathrm{m}^{-2}$ with $\mathrm{SD}$ ) of recruited barnacles on settlement plates. ( $\rightarrow$ ) Actual observations; (.) adjusted results which take into account the drop in accumulated biomass of barnacles after $40 \mathrm{~d}$ (see text). Numbers of days over which settlement was monitored are indicated, but results have been adjusted to show the biomass accumulating per month, and scaled up to $1 \mathrm{~m}^{2}$

plate and to each other and fell off. To calculate the initial production of recruiting barnacles more accurately, a $61 \mathrm{~d}$ experiment was initiated in November 1984, when barnacle recruitment was close to its peak. After $40 \mathrm{~d}$ production was restricted by the size of the plates; after this period a sharp drop in the accumulated biomass occurred (Fig. 9b). Barnacles are in any 


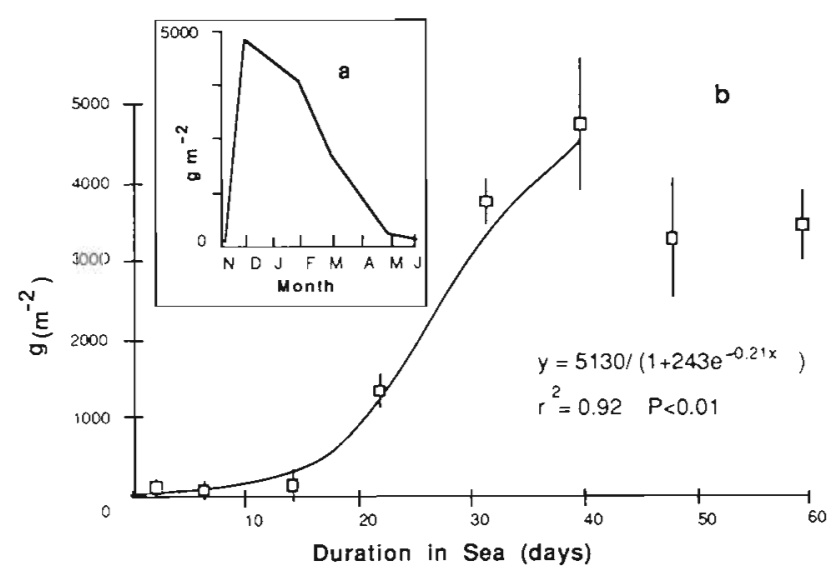

Fig. 9. Notomegabalanus algicola. Monthly (a) and daily (b) accumulation of barnacle biomass (wet weight $\mathrm{g} \mathrm{m}^{-2}$ with SD). From an initial recruitment during the peak season of settlement (November, December). The fitted logistic curve for the daily production describes only the early period $(40 \mathrm{~d})$ of settlement, before the accumulated biomass started to drop

case unlikely to survive longer than $40 \mathrm{~d}$ at Malgas Island, as discussed below. Consequently, a logistic equation relating total wet weight to age ( $A$, in days) was fitted to the daily production of barnacles for only the first $40 \mathrm{~d}$ of recruitment. After transformation of the data into units of energy, this could be expressed as:

$$
\begin{gathered}
\text { Barnacle energy content }\left(\mathrm{kJ} \mathrm{m}^{-2}\right) \\
=3403 /\left(1+32047 \mathrm{e}^{-0.47302 \mathrm{~A}}\right) .
\end{gathered}
$$

To determine the age at which Notomegabalanus algicola was consumed by Jasus lalandii, the thickness of barnacle shells found in the lobsters' guts was fitted to a regression equation relating shell plate thickness ( $\mathrm{T}$, in $\mathrm{mm}$ ) to barnacle age ( $\mathrm{A}$, in days), which was determined by subsampling barnacles of known ages from the plates.

$$
\begin{aligned}
\mathrm{T}= & 0.99817 /\left(1+43.918 \mathrm{e}^{-017236 \mathrm{~A}}\right) ; \\
& \left(n=364, r^{2}=0.92, p<0.01\right) .
\end{aligned}
$$

Using this information, it was determined that barnacles being eaten had an average minimum age of $\mathrm{ca}$ $20 \mathrm{~d}$ and an average maximum age of ca $38 \mathrm{~d}$ (Fig. 10). This information was based only on unbroken barnacle plates extracted from the gut, but very small juvenile barnacles, whose shell plates were fragmented, were also consumed. Consequently the minimum ages are overestimates, but the maximum ages are reliable. Unlike the minimum age, the maximum age of barnacles was significantly correlated with rock lobster carapace size $(r=0.75, p<0.01$; Fig. 10$)$. This suggests that small rock lobsters can only feed on the younger (smaller) barnacles, while larger ones can feed on a greater size range.

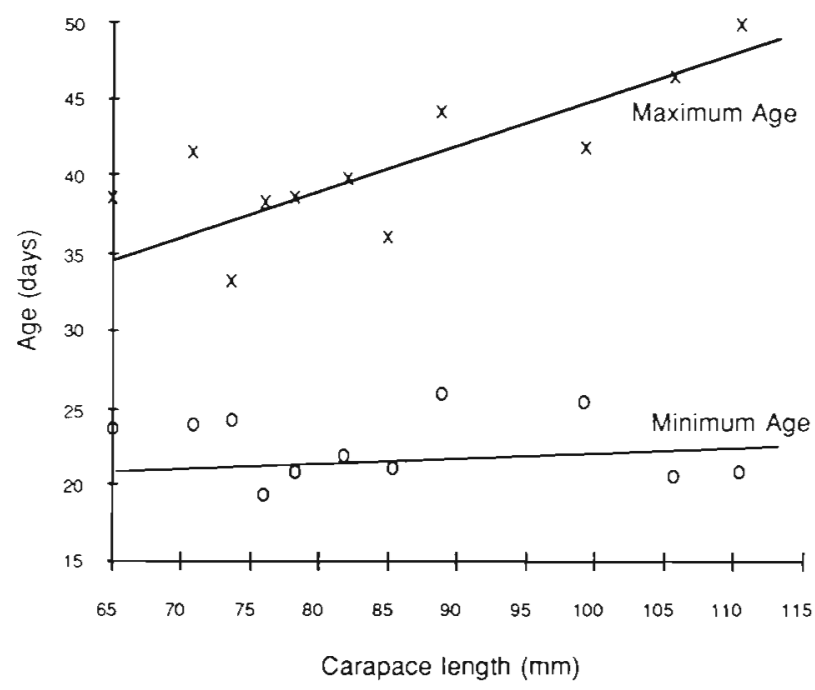

Fig. 10. Notomegabalanus algicola/Jasus lalandii. Average minimum and maximum age of barnacles eaten by rock lobsters of different carapace lengths

The next step was to calculate the annual production of Notomegabalanus algicola available for consumption by the rock lobsters. The following assumptions were made in order to simplify this calculation, but they all have the effect of making the estimation conservative: (1) Jasus lalandii feeds on the barnacles between 20 and $40 \mathrm{~d}$ after they first settle, including secondary settlements; (2) the rock lobsters clean the substratum completely when feeding; (3) one settlement of barnacles is consumed per month (mean age of barnacles eaten thus equals $30 \mathrm{~d}$ ); (4) during peak recruitment (August to March) the biomass of barnacles reaches a maximum after $40 \mathrm{~d}$ and then declines by about $35 \%$ over the subsequent $10 \mathrm{~d}$ (Fig. 9). The consequence of Assumption 4 is that production would have been higher over the initial $40 \mathrm{~d}$ of recruitment than indicated by the biomass recorded over longer periods. This decline was used to estimate the degree to which production exceeded the recorded value for biomass (Fig. 8). Assumption 4 is important because, in many cases, due to bad sea conditions, the settlement plates were monitored after periods exceeding $40 \mathrm{~d}$ (Fig. 8).

Using the data in Fig. 8, a total annual production of $36285 \mathrm{~g} \mathrm{~m}^{-2}$ (wet mass) was calculated. This is equal to a dry weight of $11975 \mathrm{~g} \mathrm{~m}^{-2} \mathrm{yr}^{-1}$. At a calorific value of $2.11 \mathrm{~kJ} \mathrm{~g}^{-1}$ (dry wt) this yields an annual production of $25265 \mathrm{~kJ} \mathrm{~m}^{-2}$ : about $70 \%$ of the total calculated annual energetic requirements of the rock lobsters at Malgas Island (36273 $\mathrm{kJ} \mathrm{m}^{-2}$ ).

However, $80 \%$ of the barnacle production is concentrated during the 7 mo of spring and summer, and during this period the barnacles can theoretically fulfill most of the rock lobsters' energy requirements. 


\section{Mussel production}

After barnacles settle, they provide a substratum for other recruits, mostly mussels, small crustaceans and tunicates. While preying on the barnacles the rock lobsters also consume these other species. If the mussels are left undisturbed, they accumulate a substantial biomass, but this takes some time (Fig. 11).

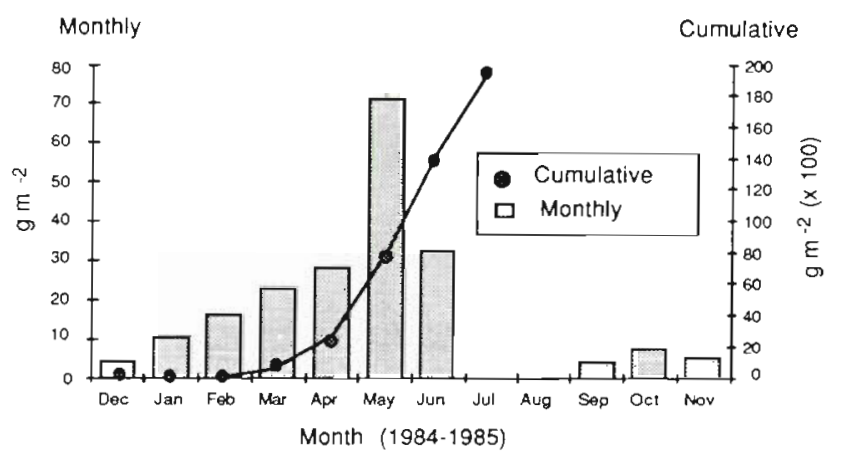

Fig. 11. Chloromytilus meridionalis and Aulacomya ater. Monthly and accumulated biomass (wet weight) of recruited mussels on the settlement plates

Mussel biomass begins to increase rapidly only $80 \mathrm{~d}$ after the onset of recruitment. Prior to this there is very little accumulation of biomass.

Mussel recruitment was high in autumn, with a monthly peak of $70 \mathrm{~g}$ (wet wt) $\mathrm{m}^{-2}$ during April (Fig. 11). Du Plessis (1977) found a similar seasonal pattern for Choromytilus meridionalis recruitment in Saldanha Bay during 1972 to 1975 .

Using the same methods as described above to calculate barnacle production, a value of $204.68 \mathrm{~g}$ $\mathrm{m}^{-2} \mathrm{yr}^{-1}$ (wet wt), or $295 \mathrm{~kJ} \mathrm{~m}^{-2} \mathrm{yr}^{-1}$, was obtained for mussel production. This is less than $1 \%$ of the annual requirement of Jasus lalandii at Malgas Island. Thus, although mussels are capable of developing a very high biomass if they are not preyed upon, their early growth within $30 \mathrm{~d}$ of recruitment at Malgas (by which time they will have been eaten by the rock lobsters) contributes only an insignificant amount of energy towards the needs of the rock lobsters in comparison to the barnacle recruits.

\section{Mysid production}

Large, dense swarms of mysids were often associated with the rocky subtidal region around Malgas Island (Barkai 1987, Branch \& Barkai 1988). These swarms extended over a depth of about $5 \mathrm{~m}$, from the sea floor to about $2 \mathrm{~m}$ below the surface. This phenomenon was observed throughout the year, but more often during winter. Mysids are common on the South African west coast especially near dense kelp beds (Carter 1983), but have never been reported as prey for rock lobsters. Despite this, in the autumn more than $50 \%$ of the identified food was composed of the mysid Mysidopsis schultzei. The rock lobsters were never observed feeding on the mysids and there is no evidence of how they may capture them. Heavy mortality of mysids may deposit thick layers on the bottom, enabling Jasus lalandii to feed on them (R. A. Carter pers. comm.). It cannot be suggested that the mysids are a regular food supply, nor is it presently possible to calculate their quantitative contribution to rock lobsters. Nevertheless, their potential importance as a source of food is very high. Given a water depth of $5 \mathrm{~m}$, a mean density of $3.3 \times 10^{5} \mathrm{~m}^{-3}$, a dry mass of $3.03 \mathrm{mg}$ per mysid and a calorific value of $18.81 \mathrm{~kJ} \mathrm{~g}^{-1}$ (Carter 1983, pers. comm.), a single swarm might be equivalent to $9.4 \times 10^{3} \mathrm{~kJ} \mathrm{~m}^{-2}$.

\section{Caging of rock lobsters}

To test if Jasus lalandii could survive solely on recruiting organisms in the absence of an established macrobenthos, rock lobsters were caged for 8 mo at Marcus Island and for $9 \mathrm{mo}$ at Malgas Island (after which a severe storm destroyed the cages). The bases of the cages were covered by plates similar to those used in the barnacle production experiment and the mesh was fine enough to exclude benthic species larger than a few millimeters. Regular checks on the condition of the caged rock lobsters at both islands showed that they all survived and were feeding on any recruits that colonised the plates within the cages. The control chambers without rock lobsters were covered after a short time with a thick layer of benthic species, while the plates and walls in the experimental chambers remained completely clean as a result of rocklobster predation on recruits.

\section{GENERAL CONCLUSIONS}

One of the main conclusions to be drawn from this study is that it will be necessary to revise the conventional view that the maintenance and growth of rock lobsters is dependent on an adequate macrobenthic standing stock. At Malgas Island the standing stock of the macrobenthos is insufficient to support more than $9 \%$ of the energetic needs of the large rock lobster population. Despite this, the rock lobsters are apparently fast growing, as shown by their high fecundity, the large size at which females become sexually mature (Beyers \& Goosen 1987) and their large average size. 
Much of the diet of the rock lobsters at Malgas Island consists of young, recently recruited barnacles, especially Notomegabalanus algicola, which potentially provides enough energy input and annual production to support the energetic needs of the rock lobsters during most months of the year. Barnacles have not previously been recorded as an important source of food for Jasus lalandii, let alone considered sufficient to meet most of their energetic requirements. Rock lobsters kept in cages where they had no access to macrobenthic organisms survived for 8 to 9 mo, consuming recruiting species shortly after they settled, and keeping the substratum bare in the process.

During times of low barnacle recruitment (winter and autumn) the rock lobsters turned to another unconventional source of food. Mysids then formed a dominant component of the gut contents and, potentially, can supply more than enough to meet the energetic needs of the rock lobsters during certain periods. Once again, there have been no previous reports of rock lobsters feeding on mysids. It remains to be determined how the rock lobsters capture mysids, but it is conceivable that they feed on dead mysids that have deposited on the bottom.

It seems that cannibalism occurred more often among the rock lobsters at Malgas Island (Figs, 6 and 7) than at other communities on the South African west coast (Heydorn 1969, Pollock pers. comm.), particularly during seasons when barnacle recruitment was sparse. Clearly rock lobsters are opportunistic and can capitalise on unorthodox sources of food which can sustain even very dense populations.

Aulacomya ater, normally the most important prey species for rock lobsters, contributed significantly to the diet of only the large specimens at Malgas Island and then only in periods when barnacle recruitment was at a low level.

Clearly it is no longer possible to quantify food availability for rock lobsters solely in terms of benthic standing stocks, as has previously been done (Heydorn 1969, Newman \& Pollock 1974a, Pollock 1979, Griffiths \& Seiderer 1980, Seiderer et al. 1982, Wickens 1985, Beyers \& Goosen 1987). In fact, much of the biomass recorded in areas where rock lobsters are dense consists of animals that are inedible, or exceed the critical size available to rock lobsters. Conversely, biomass surveys almost invariable fail to record (or, at best, underestimate) the importance of a continual input of recruits which can supply a substantial source of energy even though their biomass is not detectable by conventional sampling techniques. Substantial errors may arise in studies of energy flow which ignore the role of recruits which are consumed by carnivores shortly after settlement.
Acknowledgements. Special thanks are due to the following: Mrs R. Barkai, Dr C. L. Griffiths, Prof. J. G. Field, Dr V. Stuart, Ms P. Wickens, Ms C. Moloney, Dr D. Pollock and Mr P. Zoutendyk for useful advice. We thank Mrs Tolosana for typing and Mr P. Hanekom and Dr P. Fielding for diving assistance. Thanks also go to the South African Department of Sea Fisheries, in particular the Saldanha Bay branch. Financial support was given through the Benguela Ecology Programme of the South African National Committee for Oceanographic Research, and a University of Cape Town postgraduate scholarship.

\section{LITERATURE CITED}

Aiken, D. E. (1980). Molting and growth. In: Cobb, S., Phillips, B. F. (eds.) The biology and management of lobsters, Vol. I. Physiology and behavior. Academic Press, New York, p. 91-163

Atema, J., Cobb, J. S. (1980). Social behavior. In: Cobb, S., Phillips, B. F. (eds.) The biology and management of lobsters, Vol. I. Physiology and behavior. Academic Press, New York, p. 409-446

Barkai, A. (1987). Biologically induced alternative states in two rocky subtidal benthic communities. Ph. D thesis, University of Cape Town

Barkai, A., Branch, G. M. (1988). Contrasts between the benthic communities of subtidal hard substrata at Marcus and Malgas Islands: a case of alternative stable states? S. Afr. J. mar. Sci. 7 : in press

Beckley, L. E. (1981). Marine benthos near the Saldanha Bay iron-ore loading terminal. S. Afr. J. Zool. 16 (4): 269-271

Berry, P. F. (1971). The biology of the spiny lobster Panulirus homarus (Linnaeus) off the east coast of Southern Africa. $S$. Afr Oceanogr. Res. Inst. Invest. Rep. 28, p. 1-75

Beyers, C. J. De B., Goosen, P. C. (1987). Variation in fecundity of female rock lobster Jasus lalandii in the Benguela ecosystem. S. Afr. J. mar. Sci. 5: 513-522

Brafield, A. E., Llewellyn, M. J. (1982). Animal energetics. Blackie and Son, Glasgow and London

Branch, G. M., Barkai, A. (1988). Interspecific behaviour and its reciprocal interaction with evolution, population dynamics and community structure. In: Vannini, M., Chelazzi, G. (eds.) Behavioural adaptations to intertidal life. Plenum Press, New York

Branch, G. M., Barkai, A., Hockey, P. A. R., Hutchings, L. (1987). Biological interactions: causes or effects of variability in the Benguela ecosystem? S. Afr. J. mar Sci. 5: $425-445$

Brown, A. C., Jarman, N. (1978). Coastal marine habitats. In: Werger, M. J. A. (ed.) Biogeography and ecology of Southern Africa. W. Junk Publishers, The Hague, p. 1239-1277

Carter, R. A. (1983). The role of plankton and micronekton in carbon flow through a southern Benguela kelp bed. Ph. D. thesis, University of Cape Town

Christie, N. D., Moldan, A. (1977). Effects of fish factory effluent on the benthic macrofauna of Saldanha Bay. Mar. Pollut. Bull. 8 (2) : 41-45

Conover, R. J. (1978). Transformation of organic matter. In: Kinne, O. (ed.) Marine ecology, Vol. 4, Dynamics. John Wiley and Sons, Chichester, p. 221-499

Day, J. H. (1959). The biology of Langebaan Lagoon: a study on the effect of shelter from wave action. Trans. R. Soc. S. Afr. 35: 475-547

Du Plessis, A. J. (1977). Larval development, settlement and growth of the black mussel Choromytilus meridionalis in 
the Saldanha Bay region. Trans. R. Soc. S. Afr. 42: 303316

Field, J. G., Jarman, N. G., Dieckmann, G. S., Griffiths, C. L., Velimirov, B., Zoutendyk, P. (1977). Sun, wave, seaweed and lobsters: the dynamics of a west codst kelp-bed. S. Afr J. Sci. 73: 7-10

Field, J. G., Griffiths, C. L., Griftiths, R. J., Jarman, N. G., Zoutendyk, P., Velimirov, B. (1980). Variation in structure and biomass of kelp communities along the south west Cape coast Trans. R. Soc. S. Afr. 44: 145-203

Gardner, B. D., Connell, A. D., Eagle, G. A., Moldan, A. G. S. Oliff, W. D., Orren, M. J., Watling, R. J. (1983). South African marine pollution survey report 1976-1979. S. Afr. Natn. Scient. Prog. Rep. 73: p. 1-92

Griffiths, C. L., King. J. A. (1979). Some relationships between size, food availability and energy balance in the ribbed mussel Aulacomya ater. Mar. Biol. 51. 141-149

Griffiths, C. L., Seiderer, J. L. (1980). Rock lobsters and mussels - limitations and preferences in a predator-prey interaction. J. exp. mar. Biol. Ecol. 44: 95-109

Griffiths, R. J. (1981). Population dynamics and growth of the bivalve Choromytilus meridionalis (Kr.) at different tidal levels. Estuar coast. Shelf Sci. 12: 101-118

Heydorn, A. E. F. (1969). The rock lobster of the South African west coast Jasus lalandij (H. Milne Edwards) II. Population studies, behaviour, reproduction, moulting, growth and migration. Investl Rep. Div. Sea Fish. S. Afr. 71 : 1-52

McLeese, D. W. (1964). Oxygen consumption of the lobster, Homarus americanus Milne-Edwards. Helgoländer wiss. Meeresunters. 10: 7-18

McLeese, D. W. (1968). Oxygen consumption of the spider crab (Chionoecetes opilio) and the American lobster (Homarus americanus) at a low temperature. J. Fish. Res. Bd Can. 25: 1729-1732

Newman, G. G., Pollock, D. E. (1969). The efficiency of rock lobster fishing gear. S. Afr. Shipp. News Fish. Ind. Rev. 24 : $79-81$

Newman, G. G., Pollock, D. E. (1971). Biology and migration of rock lobster Jasus lalandii and their effect on availability at Elands Bay, South Africa. Investl Rep. Div. Sea Fish. S. Afr $94: 1-24$

Newman, G. G., Pollock, D. E. (1973). Organic pollution of the marine environment by pelagic fish factories in the western Cape. S. Afr. J. Sci. 69: 27-29

Newman, G. G., Pollock, D. E. (1974a). Growth of the rock lobster Jasus lalandii and its relationship to benthos. Mar. Biol. 24: 339-346

Newman, G. G., Pollock, D. E. (1974b). Biological cycles maturity and availability of rock lobster Jasus lalandii on two South African fishing grounds. Investl Rep. Sea Fish. Branch S. Afr 107.1-16
Pollock, D. E. (1973). Growth of juvenile rock lobster Jasus lalandii. Investl Rep. Sea Fish. Branch. S. Afr 106:1-16

Pollock, D. E. (1979). Predator-prey relationships between the rock lobster Jasus lalandii and the mussel Aulacomys ater at Robben Island on the Cape west coast of Africa. Mar. Biol. 52: 347-356

Pollock, D. E. (1982). The fishery for and population dynamics of west coast rock lobster related to the environment in the Lamberts Bay and Port Nolloth areas. Investl Rep. Sea Fish. Inst. S. Afr. 124: 1-5?

Pollock, D. E. (1986). Review of the fishery for and biology of the Cape rock lobster Jasus lalandii with notes on larval recruitment. Can. J. Fish. Aquat. Sci. 43: 2107-2117

Pollock, D. E., Augustyn, C. J., Goosen, P. C. (1982). The rock lobster Jasus lalandii and its environmental biology on the Saldanha Columbine fishing ground off the Cape west coast, 1978-1981. Investl Rep. Sea Fish. Inst. S. Afr. 125: $1-30$

Shepherd, S. A. (1973). Studies on Southern Australian abalone (genus Haliotis) I. Ecology of five sympatric species. Aust. J. mar. Freshwat. Res. 24: 217-257

Siederer, L. J., Hahn, B. D. Lawrence, L. (1982). Rock lobsters, mussels and man: a mathematical model. Ecological Modelling 17: 225-241

Silberbauer, B. I. (1971). The biology of the South African rock lobster Jasus lalandii (H. Milne Edwards) 2. The reproductive organs, mating and fertilisation. Investl Rep. Div. Sea Fish. S. Afr. 93: 1- 16

Taunton-Clark, J., Kamstra, F. (1988). Aspects of marine environmental variability near Cape Town, 1960-1985. S. Afr. J. mar. Sci. 6: 273-283

Wickens, P. A. (1985). Growth and simulation modelling studies of rock lobster (Jasus lalandii) and mussel (Aulacomya ater) populations and their interactions. M. Sc. thesis, University of Cape Town

Winget, R. (1969). Oxygen consumption and respiratory energetics in the spiny lobster, Panulinus interruptus (Randall). Biol. Bull. mar. biol. Lab., Woods Hole 136: 301-312

Zoutendyk, P. (1988a). Consumption rates of captive Cape rock lobster Jasus lalandii. S. Afr. J. mar. Sci. 6: 267-271

Zoutendyk, P. (1988b). Carbon and nitrogen losses through moulting in the Cape rock lobster Jasus Ialandii. S. Afr. J. mar Sci. Vol. 7 (in press)

Zoutendyk, P. (1988c). Nitrogen excretion by the Cape rock lobster Jasus lalandii and its possible contribution to the inshore Benguela System S. Afr. J. mar. Sci. 5: 565-574

Zoutendyk, P. (1988d). Feeding, defecation and absorption efficlency in the Cape rock lobster Jasus lalandii. S. Afr. J. mar. Sci. 6: 59-65 